\title{
Rozpoznawanie i wykrywanie przestępstwa prania brudnych pieniędzy Bułgarskie rozwiązania instytucjonalne
}

Do podjęcia badań nad funkcjonowaniem systemów przeciwdziałania tzw. praniu brudnych pieniędzy skłania fakt, że istnienie przestępczości zorganizowanej jest jednym z największych zagrożeń dla współczesnych państw demokratycznych, opartych na nadrzędności prawa. Bułgaria należy do krajów, które w wyniku transformacji politycznej są szczególnie dotknięte ta patologia. Warto postawić uzasadniona i mało ryzykowną tezę, że to nowe zagrożenie wymaga istotnego zaangażowania instytucji publicznych $\mathrm{w}$ celu przeciwdziałania niebezpieczeństwom powodowanym przez zorganizowane grupy przestępcze. Jedno z podejść do tworzenia systemu przeciwdziałania i zwalczania przestępczości zorganizowanej zakłada działania polegające na odcięciu liderów grup przestepczych od uzyskiwanych korzyści. Podejście to zyskało na znaczeniu w wielu krajach Unii Europejskiej (UE), także w Bułgarii.

W efekcie mamy do czynienia z samodzielnym systemem rozbudowanych regulacji oraz rozwiązań instytucjonalnych, których celem jest utrudnianie legalizacji korzyści pochodzących z działalności przestępczej. System ten w różnym stopniu angażuje podmioty z sektora publicznego, ale również z prywatnego. 
Zinstytucjonalizowana reakcja państwa obejmuje dwa podstawowe segmenty działań: przeciwdziałanie i zwalczanie (ściganie karne). Przeciwdziałanie zawiera zestaw regulacji prawnych, a także obowiązków organów państwowych i podmiotów prywatnych, nastawionych na uniemożliwienie organizacjom przestępczym wprowadzenia do legalnego obrotu gospodarczego środków pochodzących z przestępstwa oraz ich konwersji i transferu (z wykorzystaniem różnych produktów i podmiotów). System zwalczania procederu prania pieniędzy należy utożsamiać z funkcja ścigania karnego, obejmująca rozpoznanie przestępstwa, wykrywanie jego sprawców oraz udowadnianie ich winy.

Przeciwdziałanie i zwalczanie przypadków prania pieniędzy należy rozpatrywać nie tylko w kontekście walki z przestępczością zorganizowana, ale jako element szerszego systemu bezpieczeństwa państwa. Mam na myśli przede wszystkim bezpieczeństwo ekonomiczne, rozumiane jako zdolność państwa do zapewnienia ochrony jego interesów gospodarczych, a także prawidłowego obrotu między wszystkimi jego uczestnikami na swoim terytorium. Przy praniu pieniędzy wykorzystuje się działalność różnych uczestników obrotu gospodarczego. Powodować to może zachwianie stabilności finansowej czy też utratę zaufania do systemu finansowego wśród partnerów zagranicznych. W tym sensie przeciwdziałanie wspomnianemu przestępstwu można uznać jako wpływające na stabilność finansową.

Pranie pieniędzy dynamizuje inne kategorie przestępczości, zwłaszcza skarbową i zorganizowana. Tolerowanie procederu, czy też nieskuteczność organów kontroli lub ścigania, powodować może umacnianie się alternatywnych struktur władzy, tworzonych i kierowanych przez organizacje przestępcze, a więc zagrożenia szczególnie niebezpiecznego dla 
państwa ${ }^{1}$. Tak więc, rozpatrując rozbudowane systemy instytucjonalne, stworzone z myślą o przeciwdziałaniu praniu brudnych pieniędzy, należy pamiętać o zagrożeniach, jakie ten proceder niesie dla bezpieczeństwa państwa.

Zadania realizowane przez służby i instytucje publiczne oraz podmioty prywatne składają się na proces rozpoznawania i wykrywania procesu prania pieniędzy. Funkcja rozpoznawcza tego procesu polega na uzyskaniu możliwie dużej ilości informacji, dotyczących aktualnych i przyszłych działań przestępczych ${ }^{2}$. Wykrywanie (funkcja wykrywcza) - to ogół działań (poszukiwanie, ujawnianie, stwierdzanie) nastawionych na ujawnianie działań przestępczych. Funkcja ta powinna być powiązana z poznawcza, bowiem w ramach jej realizacji następuje aktywizacja i ukierunkowanie wiedzy uzyskanej w ramach procesu rozpoznawczego ${ }^{3}$.

Niniejszy artykuł jest próbą przedstawienia i oceny istniejącego w Republice Bułgarii systemu instytucjonalnego, stworzonego w celu skutecznej walki z legalizacją nielegalnych dochodów. Autor przedstawi przede wszystkim istniejące ramy prawne, a także wskaże wyspecjalizowane instytucje, podejmujące działania na rzecz skutecznego rozpoznawania i wykrywania przestępstw związanych z praniem pieniędzy.

$$
* * *
$$

Nie ulega wątpliwości, że w Bułgarii dostrzega się szereg działań i procesów utożsamianych z praniem brudnych pieniędzy. Dotyczy to zarówno środków napływających z zagranicy,

${ }^{1} \mathrm{~W}$. Fehler, O pojęciu bezpieczeństwa państwa, [w:] Bezpieczeństwo państw $i$ narodów $w$ procesie integracji europejskiej, pod red. W. Śmiałka, J. Tymanowskiego, Torun 2002, s. 22-23.

${ }^{2}$ T. Hanausek, Kryminalistyka. Zarys wykładu, Kraków 2005, s. 38.

${ }^{3}$ Ibidem, s. 39-40. 
jak i pochodzaçcych od rodzimej przestępczości zorganizowanej. Kraj ten, będacy obecnie centrum tranzytowym przemytu narkotyków oraz ofiar handlu ludźmi do Europy Zachodniej, jest istotnym obiektem zainteresowania transnarodowych, zorganizowanych grup przestępczych. Zdaniem specjalistów z bułgarskiej Państwowej Agencji „Bezpieczeństwa Narodowegо” (Дьржавна агениия „Национална сигурност”, DANS), w Bułgarii nielegalnych operacji finansowych dokonuja organizacje przestępcze z Rosji, Włoch, Turcji, krajów Bliskiego Wschodu, a także Chin ${ }^{4}$.

Zasadniczą przyczyna, dla której Bułgarię wykorzystuje się $\mathrm{w}$ procederze prania pieniędzy, jest niesłabnace zapotrzebowanie na inwestycje i związany z nimi napływ kapitału z zagranicy (także „brudnego” i spekulacyjnego). Dodatkowym czynnikiem jest istnienie dużej tzw. szarej strefy, która opiera się przede wszystkim na transakcjach gotówkowych ${ }^{5}$. Praniu pieniędzy sprzyja rozpowszechniona korupcja. Mimo tego, że w Bułgarii od 2007 r. podjęto wiele inicjatyw oraz zmian legislacyjnych, to istniejace przepisy prawne często nie są egzekwowane ${ }^{6}$.

Zgodnie ze sprawozdaniami Państwowej Agencji „Bezpieczeństwa Narodowego", publikowanymi w latach 2011, 2012 oraz 2013, do głównych obszarów ryzyka, związanych $\mathrm{z}$ praniem brudnych pieniędzy w Bułgarii, zaliczyć należy:

${ }^{4}$ Wystapienie Emila Kyndewa z Państwowej Agencji „Bezpieczeństwa Narodowego" podczas konferencji naukowej Przestepczość zorganizowana $i$ pranie pieniędzy, zorganizowanej przez fundację Risk Monitor 19 grudnia 2013 r. w Sofii, niepublikowane.

${ }^{5}$ Скритата икономика в България през 2013 г., „CSD Policy Brief” No 42, Център за изследване на демокрацията, http://www.csd.bg/artShowbg.php?id=16711 (dostęp 1 VIII 2014).

${ }^{6}$ Корупиия и антикорупция в Бблгария (2012-2013 г.), „CSD Policy Brief" No 43, Център за изследване на демокрацията, http://www.csd.bg/ artShowbg.php?id=16730 (dostęp 1 VIII 2014). 
przestępstwa podatkowe i celne; przemyt i obrót paliwami, alkoholem i tytoniem; handel narkotykami; budownictwo; cyberprzestępczość oraz oszustwa związane z ATM i kartami kredytowymi ${ }^{7}$.

Skala zjawiska prania pieniędzy nie jest dokładnie znana, brakuje bowiem wiarygodnych danych na ten temat w poszczególnych krajach. Wynika to z natury procederu legalizacji dochodów uzyskanych z przestępstw. Aktywność ta, jako nielegalna, odbywa się poza oficjalnymi statystykami finansowymi. Zwracaja na to uwage eksperci grupy specjalnej ds. przeciwdziałania praniu pieniędzy (Financial Action Task Force, FATF). Niemożliwe jest więc przedstawienie realnych szacunków, dotyczacych problemu. Dlatego FATF sama nie opracowuje ani nie publikuje danych na ten temat ${ }^{8}$.

\section{Poszukiwanie skutecznych rozwiązań prawnych $\mathrm{i}$ instytucjonalnych}

Rządowa Strategia przeciwdziałania praniu pieniędzy na lata 2011-2015 definiuje to zjawisko jako proces ukrywania, poprzez różne formy aktywności przestepczego pochodzenia własności, przez co umożliwia jej integracje z legalna gospodarka ${ }^{9}$. Zgodnie z powyższym zapisem oraz brzmieniem art. 2 ust. 1 Ustawy o zwalczaniu prania pieniędzy, pranie brudnych pieniędzy jest obecne w następujących przypadkach:

${ }^{7}$ Годишни доклади за дейността на САД „Финансово Разузнаване” - ДАНС за 2011 г., 2012 г., 2013 г., http://www.dans.bg/bg/msip-091209-menu-bul/fidannualreports30052012-mitem-bul (dostęp 1 VII 2014).

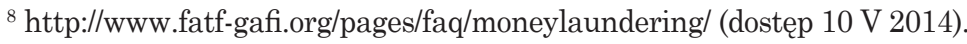

${ }^{9}$ Стратегия за противодействие на изпирането на пари в Република Бблгария 2011-2015 година, http://www.strategy.bg/StrategicDocuments/View.aspx?lang=bg-BG\&Id=709 (dostęp 1 VII 2014). 
- konwersji lub przekazania mienia nabytego z działalności przestępczej lub z aktu uczestnictwa w takiej działalności;

- w celu zatajenia lub ukrycia nielegalnego pochodzenia tego mienia lub udzielenia pomocy osobie, która uczestniczy w popełnieniu takiego czynu, by uniknąć konsekwencji prawnych tego przestępstwa;

- zatajenia lub ukrycia charakteru, źródła, miejsca przechowywania, przemieszczania lub praw do mienia nabytego z działalności przestępczej lub z aktu uczestnictwa w takiej działalności;

- nabycia, posiadania lub korzystania z mienia, ze świadomością $\mathrm{w}$ momencie jego otrzymania, że pochodzi ono z działalności przestępczej lub z aktu uczestnictwa w takiej działalności;

- udziału w jednym z powyższych działań, zmowie w celu popełnienia takiego aktu, usiłowania popełnienia i pomocnictwo, nakłaniania, ułatwiania popełniania takiego czynu lub jego ukrywania ${ }^{10}$.

Do połowy lat 90. ubiegłego stulecia wysiłki władz bułgarskich koncentrowały się w głównej mierze na zwalczaniu czynów zabronionych, prowadzących dopiero do uzyskania brudnych pieniędzy. Poszukując skutecznych metod przeciwdziałania i zwalczania przestępczości zorganizowanej, bułgarski ustawodawca wprowadził w 1998 r. penalizację wspomnianego przestępstwa. Artykuł 253 ust. 1 Kodeksu karnego przewiduje odpowiedzialność karną dla osoby, która dokonuje transakcji finansowych, transakcji nieruchomościa lub ukrywa pochodzenie, miejsce przechowywania, przebywania lub rzeczywiste prawa do nieruchomości, która posiada

10 Чл. 2, ал. 1, Закон за мерките срещу изпирането на пари, Обн. ДВ. бр. 85 от 24 Юли 1998 г., http://www.lex.bg/bg/laws/ldoc/2134420482 (dostęp 1 VII 2014). 
informacje lub podejrzewa, że pochodzq one z przestepstwa lub innego czynu społecznie niebezpiecznego ${ }^{11}$. Czyn ten zagrożony jest kara pozbawienia wolności od jednego roku do lat sześciu oraz karą grzywny w wysokości od 3 tys. do 5 tys. lewów ${ }^{12}$. Jeśli proceder prania pieniędzy jest efektem zmowy lub działań zorganizowanych, wówczas sprawca podlega karze pozbawienia wolności od jednego do ośmiu lat oraz karze grzywny w wysokości od 5 tys. do 20 tys. lewów ${ }^{13}$.

Niezwykle ciekawa konstrukcja, nie stosowaną w kodeksach karnych innych krajów w odniesieniu do procederu prania pieniędzy, jest nadzwyczajne obostrzenie kary. Artykuł 253 ust. 5 przewiduje karę pozbawienie wolności od 5 do 15 lat oraz grzywnę w wysokości od 10 tys. do 30 tys. lewów w przypadku, gdy fundusze lub nieruchomości sa szczególnie duże, a sprawa jest szczególnie poważna ${ }^{14}$.

Wprowadzenie kryminalizacji przestępstwa prania pieniędzy było zaledwie pierwszym krokiem w walce z nim. Zarówno kryminolodzy, jak i praktycy z organów ścigania i wymiaru sprawiedliwości dostrzegali, że problem efektywności ścigania tego przestępstwa musi być ujęty w specjalnie opracowany system. W latach 1998-2003 stworzono prawne mechanizmy, czyli podstawową część systemu. W tym czasie uchwalono i wprowadzono $\mathrm{w}$ życie penalizację prania pieniędzy, znowelizowano ustawę o działalności gospodarczej (poprzez rozszerzenie zakresu obrotu bezgotówkowego), zmieniono prawo bankowe. Natomiast system instytucjonalny, a właściwie jego najważniejsza część, dotycząca przeciwdziałania praniu pieniędzy

11 Чл. 253, ал. 1, Наказателен кодекс, http://sacp.government.bg/normativna-uredba/kodeksi/nakazatelen-kodeks/ (dostęp 1 VII 2014).

${ }^{12}$ Ibidem.

13 Чл. 253, ал. 3, Наказателен кодекс.

14 Чл. 253, ал. 5, Наказателен кодекс. 
i innych form przestępczości zorganizowanej, weszła w życie właściwie dopiero po $2007 \mathrm{r}$.

Badacze, zajmujacy się problematyką prania brudnych pieniędzy, wyróżniaja dwa podstawowe rozwiązania modelowe przeciwdziałania temu przestępstwu.

Pierwsze, oparte na uregulowaniach USA, jest najbardziej pracochłonne i najbardziej zbiurokratyzowane. Polega na rygorystycznym prowadzeniu rejestrów określonych transakcji przez zobowiązane ustawowo instytucje finansowe i przesyłanie ich do jednej (w tym przypadku The Financial Crimes Enforcement Network). Wykorzystanie tego modelu jest uniwersalne, gdyż ułatwia wykrywanie nie tylko prania pieniędzy, lecz przede wszystkim oszustw finansowych, podatkowych, celnych itp. Drugi model, tzw. brytyjski, polega na profesjonalnym typowaniu przez pracowników banków transakcji podejrzanych. Kwota transakcji odgrywa drugoplanową rolę, gdyż istotny jest podejrzany charakter operacji. Ujawnione transakcje są zgłaszane do specjalnej jednostki wywiadu finansowego ${ }^{15}$.

$\mathrm{Na}$ gruncie bułgarskim podstawę regulacji w zakresie przeciwdziałania praniu pieniędzy i jego zwalczania stanowią przepisy specjalnej ustawy ${ }^{16}$ oraz dołączone do niej akty wykonawcze ${ }^{17}$, jak również ustawa o zwalczaniu finansowania terroryzmu ${ }^{18}$

${ }^{15}$ M. Reider-Gordon, U.S. and International Anti-Money Laundering Developments, „International Lawyer” 2011, vol. 45, no. 1, s. 365-369, 376377; D. Masciandaro, Money laundering: The economics of regulation, „European Journal of Law and Economics" 1999, vol. 7, no. 3, s. 229-237.

16 Закон за мерките срещу изпирането на пари.

${ }^{17}$ Правилник за прилагане на Закона за мерките срешу изпирането на пари, Обн. ДВ, бр. 65 om 11.08 .2006 г., http://www.dans. bg/images/stories/promzak/pravilnik_zmip-28032013.pdf (dostęp 1 VII 2014).

18 Закон за мерките срещу ббинансирането на тероризма, Обн. ДВ, бр. 16 om 18.02.2003 г., http://www.dans.bg/images/stories/promzak/ zmft-09042013.pdf (dostęp 1 VII 2014). 
oraz wspomniany art. 253 Kodeksu karnego ${ }^{19}$, penalizujacy przestępstwo prania pieniędzy.

Analiza tych aktów prawnych wskazuje, że w przypadku Bułgarii zdecydowano się na przyjęcie brytyjskiego modelu przeciwdziałania praniu brudnych pieniędzy. Nie powinno to zreszta dziwić, ponieważ jest to efekt integracji tego kraju z Unią Europejska i dostosowania tworzonego systemu do Dyrektywy Rady Wspólnot Europejskich z 10 czerwca 1991 r. w sprawie ochrony systemu finansowego przed wykorzystaniem go do celów prania pieniędzy ${ }^{20}$ oraz Dyrektywy 2005/60/WE Parlamentu Europejskiego i Rady Europejskiej z 26 października 2005 r. w sprawie przeciwdziałania korzystaniu $\mathrm{z}$ systemu finansowego $\mathrm{w}$ celu prania pieniędzy oraz finansowania terroryzmu ${ }^{21}$.

\section{System przeciwdziałania praniu pieniędzy w Bułgarii - uregulowania instytucjonalno-prawne}

Wspomniana ustawa o zwalczaniu prania pieniędzy wskazuje na Państwową Agencje „Bezpieczeństwa Narodowego” oraz, będąca jej jednostką wyspecjalizowana, Specjalistyczną

19 Чл. 253, Наказателния кодекс.

${ }_{20}^{20}$ Директива на Сввета на Европейските общности от 10 юни 1991 година относно предотвратяване използването на финансовата система за изпиране на пари, (91/308/ЕИО), 28 VI 1991, http://eur-lex. europa.eu/LexUriServ/LexUriServ.do?uri=DD:09:01:31991L0308:bg:PDF (dostęp 1 VII 2014).

${ }^{21}$ Dyrektywa 2005/60/WE Parlamentu Europejskiego i Rady Europejskiej z 26 października 2005 r. w sprawie przeciwdziatania korzystaniu $z$ systemu finansowego $w$ celu prania pieniędzy oraz finansowania terrory$z m u$, L309/15, http://eur-lex.europa.eu/LexUriServ/LexUriServ.do?uri=OJ: L:2005:309:0015:0015:PL:PDF (dostęp 1 VII 2014). 
Dyrekcję Administracyjna „Wywiadu Finansowego” (Cneuuaлизирана административна дирекиия „Финансово разузнаване", dalej: Dyrekcja Wywiadu Finansowego) jako główne instytucje systemu przeciwdziałania i zwalczania przestępstwa prania brudnych pieniędzy.

DANS została utworzona w styczniu 2008 r. z połaczenia czterech instytucji: Narodowej Służby Bezpieczeństwa (Национална служба „Сигурност”) oraz Dyrekcji Ochrony Łączności (Дирекиия „Защита на средствата за вргзка") podległych ministrowi spraw wewnętrznych, jednostek wydzielonych ze struktur Służby Bezpieczeństwa (Служба „Сигурност”) podległej ministrowi obrony - kontrwywiadu wojskowego i żandarmerii wojskowej (военно контраразузнаване и военна полиция), oraz Agencji Wywiadu Finansowego, funkcjonujaccej w Ministerstwie Finansów (Агенцията за фбинансово разузнаване). Głównym powodem powstania nowej „superjednostki” była chęć walki z korupcją i przestępczościa zorganizowaną na wysokim szczeblu instytucjonalnym. Rząd bułgarski przedstawiał utworzenie DANS jako odpowiedź na dotychczasowy brak skuteczności w zwalczaniu groźnej przestępczości ${ }^{22}$.

Jednak tworzenie tej „superinstytucji” zakłóciło kilka kwestii majacych wpływ na jej funkcjonowanie. Po pierwsze, mandat i uprawnienia tej Agencji stały się obiektem politycznych kłótni. Brak narodowej strategii bezpieczeństwa w okresie, gdy rozpoczęto proces tworzenia DANS, rodził pytania o strategiczną rolę tej instytucji i utrudniał jej powstanie. W efekcie narodziła się jako instytucja hybrydowa, której powierzono zadania wywiadowcze, śledcze,

22 Й. Николов, ДАНС - исторично и истерично, „Капитал”, 18 X 2008, http://www.capital.bg/politika_i_ikonomika/bulgaria/2008/10/18/567330_ dans_-_istorichno_i_isterichno/ (dostęp 25 VII 2014). 
informacyjne, a jednocześnie nadano uprawnienia policyj$n e^{23}$. Głównym problemem było pomieszanie zadań wywiadowczych i dochodzeniowych. Państwowa Agencja „Bezpieczeństwa Narodowego" miała być przede wszystkim służba wywiadu/kontrwywiadu. W efekcie nadal panuje niejasność dotycząca jej uprawnień operacyjnych, mandatu, współdziałania z prokuratura, Ministerstwem Spraw Wewnętrznych itp. ${ }^{24}$

Po reformie służb specjalnych, dokonanej w 2008 r., jedna z komórek organizacyjnych DANS została Dyrekcja Wywiadu Finansowego, dotychczas funkcjonująca w Ministerstwie Finansów jako Agencja Wywiadu Finansowego (Агенция за фбинансово разузнаване). Zadania Dyrekcji obejmuja przede wszystkim otrzymywanie, gromadzenie, przetwarzanie $i$ analizowanie informacji finansowych $w$ trybie określonym $w$ przepisach Ustawy o zwalczaniu prania pieniędzy oraz Ustawy o zwalczaniu finansowania terroryzmu $u^{25}$. Ponadto Dyrekcja Wywiadu Finansowego jest odpowiedzialna za wymianę z partnerami zagranicznymi informacji dotyczących prania pieniędzy oraz finansowania terroryzmu, jak również posiada uprawnienia kontrolne w stosunku do wszystkich „instytucji obowiązanych", wymienionych w art. 3 ust. 2 i ust. 3 Ustawy o przeciwdziałaniu praniu pieniędzy.

${ }^{23}$ Zob. чл. 18-43, Закон за Държавна Агенция «национална сигурност», Обн. ДВ. бр. 109 от 20 Декември 2007 г., http://lex.bg/laws/ ldoc/2135574489 (dostęp 25 VII 2014).

${ }^{24}$ ДАНС - каква и защо? Стенограма от конферениия на РискМонитор, «Капитал», бр. 45, 8-14 ноември 2008, http://riskmonitor.bg/js/tiny_mce/plugins/ajaxfilemanager/upload/Articles/Capital08112008-SANS_discussion_1.pdf (dostęp 25 VII 2014).

${ }_{25}^{25}$ Дьржавна агениия „Наиионална сигурност”, Мерки срешу изпирането на пари, http://www.dans.bg/bg/msip-091209-menu-bul (dostęp 25 VII 2014). 
Podstawowym zadaniem Dyrekcji Wywiadu Finansowego jest pośredniczenie pomiędzy instytucjami finansowymi i organami ścigania, przede wszystkim przyspieszenie oraz ułatwienie wymiany informacji między nimi, przy zachowaniu gwarancji pełnej autonomii podejmowanych decyzji i ochrony otrzymanych informacji. Z ustawowych zadań i uprawnień wynika niezbicie, że bułgarska jednostka wywiadu finansowego ma charakter administracyjny. Dyrekcja Wywiadu Finansowego nie posiada funkcji operacyjno-rozpoznawczych, nie jest także uprawniona do podejmowania czynności dochodzeniowo-śledczych, typowych dla organów ścigania. Jej rola jest zawiadamianie prokuratury o podejrzeniu popełnienia przestępstwa z art. 253 Kodeksu karnego w sytuacji, gdy uzyskany materiał uzasadnia takie podejrzenie ${ }^{26}$. Zasadniczo więc działalność bułgarskiej jednostki analityki finansowej polega na analizowaniu informacji uzyskiwanych od instytucji obowiązanych, jednostek współpracujących oraz organów ścigania (jako specyficznej grupy jednostek współpracujących). Dyrekcja Wywiadu Finansowego analizuje informacje z powyższych źródeł w celu wykrycia przypadków wzbudzajaccych uzasadnione podejrzenia prania pieniędzy lub wskazujących na działalność, o której powinny być powiadomione organy ścigania.

Należy zauważyć, że umiejscowienie Dyrekcji Wywiadu Finansowego $\mathrm{w}$ strukturze agencji bezpieczeństwa bez wątpienia korzystnie wpływa na jej możliwości ścisłej współpracy z bułgarskimi służbami porządku publicznego, służbami

${ }^{26}$ Brak uprawnień do podejmowania czynności dochodzeniowo-śledczych skutkuje brakiem możliwości ustalenia źródła pochodzenia środków finansowych, a więc stwierdzenia czy analizowane transakcje faktycznie mają związek z popełnieniem przestępstwa z art. 253 Kodeksu karnego. W efekcie Dyrekcja Wywiadu Finansowego kieruje do prokuratury zawiadomienia o podejrzeniu popełnienia przestępstwa, a nie o jego popełnieniu. 
bezpieczeństwa, a także ich zagranicznymi odpowiednikami. Dotyczy to nie tylko wykrywania i zapobiegania praniu pieniędzy, ale także przepływów kapitału, korupcji czy przekupstw w międzynarodowych transakcjach handlowych.

Jednostka analityki finansowej jest centralnym podmiotem systemu przeciwdziałania i zwalczania prania pieniędzy w Bułgarii. Elementami tego systemu sa również: instytucje obowiązane i jednostki współpracujące (jako dostawcy informacji) oraz organy ścigania i prokuratura (jako finalni ich odbiorcy).

Niezmiernie ważna, a jednocześnie szeroką i charakteryzująca się brakiem ustawowej definicji, jest kategoria „instytucje obowiązane”. Należy jednak domniemywać, że zgodnie z ich zadaniami statutowymi - sa to głównie struktury finansowe, które mają związek z obrotem pieniężnym i gospodarczym.

Bułgarska ustawa o zwalczaniu prania pieniędzy określa jeden z najszerszych w UE katalog instytucji obowiązanych. Zgodnie z art. 3 ust. 2 obejmuje ona 30 kategorii instytucji, organizacji i osób, które muszą postępować zgodnie z zasadami, procedurami i praktykami, służącymi uniknięciu ewentualnego prania środków pochodzących z nielegalnych źródeł. Pełny katalog instytucji obowiązanych obejmuje:

1) Narodowy Bank Bułgarii; instytucje kredytowe, działające w Republice Bułgarii; instytucje finansowe; biura wymiany walut i innych dostawców usług płatniczych;

2) ubezpieczycieli i pośredników ubezpieczeniowych z siedzibą w Republice Bułgarii; ubezpieczycieli i pośredników ubezpieczeniowych państwa-członka UE lub państwa-strony umowy o Europejskim Obszarze Gospodarczym, działających na terytorium Republiki Bułgarii; ubezpieczycieli z siedzibą w krajach innych niż wyżej wymienione, które uzyskały 
licencję Komisji Nadzoru Finansowego na prowadzenie (poprzez swój oddział) działalności w Bułgarii;

3) przedsiębiorstwa inwestycyjne i spółki zarządzające;

4) towarzystwa ubezpieczeń zdrowotnych i emerytalnych;

5) organy prywatyzacyjne;

6) podmioty organizujące zamówienia publiczne;

7) podmioty prowadzące działalność $\mathrm{w}$ zakresie gier losowych;

8) osoby prawne, prowadzące kasy samopomocowe;

9) podmioty, które udzielają pożyczek pod zastaw;

10) operatorzy pocztowi, posiadający licencję na prowadzenie usług w zakresie przekazów pieniężnych;

11) notariusze;

12) operatorzy na rynkach regulowanych;

13) firmy leasingowe;

14) organy państwowe i samorządowe, udzielające koncesji;

15) partie polityczne;

16) związki i stowarzyszenia zawodowe;

17) fundacje i stowarzyszenia non-profit;

18) biegli rewidenci;

19) organy Państwowego Urzędu Skarbowego;

20) organy celne;

21) organizacje sportowe;

22) Centralny Depozyt Papierów Wartościowych;

23) podmioty, prowadzące działalność w zakresie handlu bronia, ropą naftową i produktami naftowymi;

24) doradcy podatkowi;

25) hurtownie i hurtownicy;

26) osoby, świadczące pomoc prawna, dotycząca sprzedaży nieruchomości, zarządzania pieniędzmi, papierami wartościowymi lub innymi aktywami finansowymi, pozyskania środków, służących podwyższeniu kapitału firmy lub innych form pozyskiwania środków na działalność przedsiębiorcy; 
działające na rzecz lub w imieniu klienta, w transakcjach finansowych lub na rynku nieruchomości;

27) podmioty, pośredniczace w obrocie nieruchomościami;

28) podmioty, rejestrujące usługi osoby prawnej, spółki offshore, firmy powierniczej lub innej podobnej struktury;

29) podmioty, prowadzące działalność w zakresie usługowego prowadzenia ksiagg rachunkowych;

30) komornicy sądowi ${ }^{27}$.

Jest to lista znacznie dłuższa niż np. w przypadku polskiej Ustawy o przeciwdziałaniu praniu pieniędzy oraz finansowaniu terroryzmu z dnia 16 listopada 2000 r. (obejmującej jedynie 20 kategorii). W Bułgarii w katalogu instytucji obowiązanych umieszczono podmioty niespotykane w takim zestawie w innych krajach: partie polityczne czy organizacje sportowe. Weryfikacja danych w BULSTAT wykazuje, że całkowita liczba instytucji, ujętych w wykazie podmiotów obowiązanych, wynosi ponad 120 tys. $^{28}$

Wszystkie podmioty, które wymieniono w art. 3 ust. 2 Ustawy o zwalczaniu prania pieniędzy, zobowiązane sa do wprowadzenia własnych, wewnętrznych standardów, służących m.in.: identyfikacji klientów oraz ich weryfikacji, bieżącego monitorowania relacji handlowych, kontroli czynności i umów realizowanych w ramach stosunków handlowych, czy ujawniania informacji na temat podejrzanych działań. Instytucje obowiązane musza, w ciagu czterech miesięcy od rejestracji, przyjąc stosowne przepisy wewnętrzne w zakresie kontroli i zapobiegania praniu pieniędzy, które jasno określa politykę i procedury dla tej działalności ${ }^{29}$. Wspomniane normy należy przesłać do Dyrekcji Wywiadu Finansowego, gdzie

\footnotetext{
27 Чл. 3, ал. 2, Закон за мерките срещу изпирането на пари.

${ }^{28}$ http://bulstat.registryagency.bg/ (dostęp 10 IX 2014).

29 Чл. 16, ал. 1, Закон за мерките срещу изпирането на пари.
} 
podlegają zatwierdzeniu przez Prezesa Państwowej Agencji „Bezpieczeństwa Narodowego”. W przypadku, gdy przepisy wewnętrzne muszą zostać uzupełnione, poprawione lub zmodyfikowane, Dyrekcja Wywiadu Finansowego sporządza oficjalny dokument, zawierający instrukcje w sprawie usuwania rozbieżności w przedłożonym projekcie. Zgodnie z art. 19 ust. 3 Regulaminu wykonawczego do Ustawy o zwalczaniu prania pieniędzy, instytucje sa zobligowane skorygować niezgodności i dostosować je do zaleceń Dyrekcji Wywiadu Finansowego, a następnie przesłać je do Państwowej Agencji „Bezpieczeństwa Narodowego" w ciagu jednego miesiąca ${ }^{30}$.

Wśród głównych zadań, nałożonych przez ustawodawcę na instytucje obowiązane, należy wymienić przede wszystkim:

- identyfikację i weryfikację klientów;

- gromadzenie informacji nt. celu i charakteru relacji finansowych, handlowych i zawodowych klientów;

- prowadzenie rejestru określonych transakcji;

- typowanie i ujawnianie Dyrekcji Wywiadu Finansowego informacji o podejrzanych transakcjach i klientach;

- udzielanie odpowiednich informacji Dyrekcji Wywiadu Finansowego na jej żądanie ${ }^{31}$.

Ustawa o zwalczaniu prania pieniędzy określa ponadto instytucje, które w granicach swoich ustawowych kompetencji zobowiązane sa współpracować z Dyrekcją Wywiadu Finansowego $\mathrm{w}$ zakresie zapobiegania przestępstwom prania pieniędzy. Jednostkami współpracującymi w myśl art. 3a ust. 3; art. 18 oraz art. 12 ust. 4 Ustawy o zwalczaniu prania

30 Чл. 19, ал. 3, Правилник за прилагане на Закона за мерките срещу изпирането на пари, Обн. ДВ. бр. 65 от 11 Август 2006 г., изм. и доп. ДВ. бр. 27 от 15 Март 2013 г., http://www.lex.bg/bg/laws/ldoc/2135533655 (dostęp 15 IX 2014).

31 Чл. 3, Закон за мерките срещу изпирането на пари. 
pieniędzy są organy administracji rządowej i samorządu terytorialnego, a także Bułgarski Bank Narodowy, Komisja Nadzoru Finansowego oraz Narodowa Agencja Skarbowa ${ }^{32}$.

Szczególna, de facto, odrębną grupa jednostek współpracujacych, sa instytucje określone w Postanowieniach dodatkowych do Ustawy o zwalczaniu prania pieniędzy jako stu̇̇by bezpieczeństwa i stużby porzqdku publicznego. Obowiązkiem tych służb jest niezwłocznie informować Dyrekcję Wywiadu Finansowego o wszystkich przypadkach uzyskania informacji, wskazujących na popełnienie przestępstwa prania pieniędzy, wszczęcia i zakończenia postępowania w tych sprawach czy przedstawienia zarzutu popełnienia tychże przestępstw. Dokument wymienia Krajową Służbę Wywiadu i Służbę „Informacji Wojskowej” - podległe Ministerstwu Obrony i Ministerstwu Spraw Wewnętrznych - jako służby bezpieczeństwa. Natomiast wśród służb porządku publicznego, zobowiązanych do współpracy z Dyrekcją Wywiadu Finansowego, wymienione zostały: Komenda Główna Policji, Straż Graniczna, Służby Ochrony Ludności i Bezpieczeństwa Pożarowego, regionalne biura Ministerstwa Spraw Wewnętrznych oraz Żandarmeria Wojskowa, podległa ministrowi obrony ${ }^{33}$.

Dyrekcja Wywiadu Finansowego przekazuje, oprócz zawiadomień o podejrzeniu popełnienia przestępstwa prania pieniędzy, także odpowiedzi na prośby i wnioski, kierowane do jednostki przez organy ścigania i inne uprawnione podmioty. Należy zaznaczyć, że ustawa nadała prokuraturze uprawnienia do uzyskiwania informacji od jednostki wywiadu finansowego na potrzeby każdego postępowania karnego, bez

32 Чл. 3а, ал. 3; чл. 18; чл. 12, ал. 4, Закон за мерките срещу изпирането на пари.

${ }_{33} \S 1$ Допълнителни Разпоредби, Закон за мерките срещу изпирането на пари. 
względu na to, czy prowadzone jest ono w związku z praniem pieniędzy, czy też nie ${ }^{34}$. Jest to rozwiązanie zrozumiałe, bowiem celem większości przestępstw jest uzyskanie korzyści majątkowych, które w dalszej kolejności muszą podlegać procesowi legalizacji. Także pozostałe podmioty, określone w Postanowieniach dodatkowych do Ustawy o zwalczaniu prania pieniędzy jako służby bezpieczeństwa i stu̇̇by porzadku publicznego, sa uprawnione, w zakresie ich kompetencji ustawowych, do uzyskiwania od Dyrekcji Wywiadu Finansowego informacji, będących w jej posiadaniu. Kompetencje te nie są jednak ograniczone do ścigania tylko przestępstw prania pieniędzy.

Praktyczna współpraca i koordynacja działań pomiędzy Dyrekcja Wywiadu Finansowego, organami ścigania oraz prokuratura, realizowana zgodnie z wymogami Ustawy o zwalczaniu prania pieniędzy, opiera się na stałych i doraźnych grupach, tworzonych zgodnie z instrukcjami wspótpracy instytucji zaangażowanych $\mathrm{w}$ zapobieganie i zwalczanie procederu prania pieniędzy. Wspomniana instrukcja wspótpra$c y$ jest umową pomiędzy dwoma lub większą liczbą organów państwa, która ustala konkretne narzędzia i mechanizmy współpracy oraz wymiany informacji. Obecnie takie umowy podpisane sa przez prawie wszystkie zainteresowane strony, tworząc gęstą sieć wzajemnych relacji, które są ściśle określone pod względem prawnym. Nie wchodząc w szczegóły tych dokumentów, można stwierdzić, że wszystkie mają podobna budowę. Typowe mechanizmy współpracy, regulowane przez instrukcje wspótpracy, obejmują:

- wyznaczenie punktów kontaktowych;

- ustanowienie wspólnych grup roboczych w sprawach operacyjnych (zarówno stałych, jak i doraźnych);

${ }_{34}$ Чл. 13, Закон за мерките срещу изпирането на пари. 
- udzielanie pomocy eksperckiej;

- tworzenie i korzystanie z kanałów wymiany informacji takich, jak bezpośredni dostęp do odpowiednich baz danych;

- wspólne szkolenia itp.

Analizujac funkcjonowanie systemu przeciwdziałania praniu pieniędzy, warto wspomnieć o bliskiej współpracy Dyrekcji Wywiadu Finansowego z organami ścigania, w szczególności z wydzielona jednostką policji ds. walki z przestępczością zorganizowana (Главна дирекиия „Борба с организираната nрестьпност') oraz z prokuratura. Podmioty te w szerokim zakresie korzystaja z informacji, posiadanych przez jednostkę analityki finansowej, oraz z danych o transakcjach ${ }^{35}$.

Ze względu na międzynarodowy wymiar przestępstw prania pieniędzy, bułgarska Dyrekcja Wywiadu Finansowego wymienia informacje $\mathrm{z}$ zagranicznymi jednostkami analityki finansowej. Jest to realizowane na podstawie porozumień dwustronnych oraz Decyzji Rady UE 2000/632/WSiSW z dnia 17 października 2000 r., dotyczacej uzgodnień w sprawie wspótpracy pomiędzy jednostkami wywiadu finansowego Państw Członkowskich $w$ odniesieniu do wymiany informacji ${ }^{36}$. Pracownicy bułgarskiej jednostki analityki finansowej uczestniczą także w pracach organizacji międzynarodowych, działających w dziedzinie przeciwdziałania praniu pieniędzy: Grupy Egmont oraz Komitetu Ekspertów ds. Oceny Systemów Zwalczania Procederu Prania Pieniędzy i Finansowania Terroryzmu (Committee of Experts on the Evaluation of Anti-Money Laundering Measures and the Financing of Terrorism, MONEYVAL).

35 Чл. 13, Закон за мерките срещу изпирането на пари.

${ }^{36}$ Решение на Сввета от 17 октолври 2000 година относно условията за сътрудничество и облен на инборлаиия между звената за ббинансово разузнаване на държавите-членки, ОВ L 271, 24 X 2000, s. 4. 
Na uwagę zasługuje fakt, że w większości raportów, wymienionych wyżej instytucji międzynarodowych, bułgarski system instytucjonalny, dotyczący przeciwdziałania praniu pieniędzy, oceniany jest niezwykle wysoko. W odniesieniu do ostatnich kilku lat należy odnotować następujące obserwacje, poczynione przez MONEYVAL:

1) bułgarskie ramy prawne postrzegane sa jako $w$ znacznej mierze zgodne z międzynarodowymi standardami $w$ zakresie zwalczania prania brudnych pieniędzy;

2) Bułgaria posiada wyspecjalizowaną instytucję do zwalczania prania pieniędzy;

3) istnieja specjalne mechanizmy, pozwalające na współpracę między różnymi instytucjami, zaangażowanymi w zwalczanie prania pieniędzy;

4) w ostatnich latach zwiększa się liczba wyroków skazujących za proceder prania pieniędzy ${ }^{37}$.

$$
* * *
$$

Pomimo pochlebnych ocen, dotyczących bułgarskiego systemu instytucjonalno-prawnego, Bułgaria nie prowadzi skutecznej polityki przeciwdziałania praniu pieniędzy. W tej sytuacji należy poszukać odpowiedzi na pytanie: Dlaczego, pomimo pozytywnych opinii, kraj ten nie odnosi w tej dziedzinie sukcesów?

${ }^{37}$ Zob. Committee of Experts on the Evaluation of Anti-Money Laundering Measures and the Financing of Terrorism (MONEYVAL). Third Round Detailed Assessment Report on Bulgaria, 1 IV 2008, http:// www.coe.int/t/dghl/monitoring/moneyval/Evaluations/round3/MONEYVAL\%282008\%2902Rep-BUL3_en.pdf; Bulgaria. Progress report and written analysis by the Secretariat of Core Recmmendations, MONEYVAL, 11 IV 2011, http://www.coe.int/t/dghl/monitoring/moneyval/Evaluations/ Progress\%20reports\%202y/MONEYVAL\%282011\%295_ProgRep2_BLG.pdf (dostęp 15 V 2014). 
Podstawowym problemem jest stosowanie przyjętych przepisów w praktyce. W artykule wspomniano, że całkowita liczba struktur, ujętych w 30 kategoriach instytucji zobowiązanych $\mathrm{w}$ art. 3 Ustawy o zwalczaniu prania pieniędzy, przekracza 120 tys. Georgi Petrunow ${ }^{38}$ z Fundacji Risk Monitor ocenił, że swoje obowiązki, związane z przygotowaniem wewnętrznych standardów, nałożone przez tę ustawę, wypełnia około 10-15 tys. instytucji i osób ${ }^{39}$. Ponadto formalne istnienie zasad nie gwarantuje ich przestrzegania, jeśli nie funkcjonuje ciagły monitoring oraz ewentualne sankcje. Według rocznego sprawozdania Dyrekcji Wywiadu Finansowego, w 2011 r. 95\% informacji o podejrzanych transakcjach zostało przekazanych przez banki i agencje rządowe (głównie organy administracji celnej i podatkowej) ${ }^{40}$. Oznacza to, że pozostałe 27 kategorii wymienionych $\mathrm{w}$ art. 3 Ustawy o zwalczaniu prania pieniędzy, nie wypełniało należycie swoich obowiązków, wynikających z tego aktu prawnego.

Kolejnym problemem są różnego rodzaju tajemnice: bankowa, podatkowa, handlowa itp., które utrudniaja pracę Dyrekcji Wywiadu Finansowego czy organom ścigania. Każdorazowo uzyskanie dostępu do takiej informacji wymaga uzyskania zgody sądu, co wydłuża dochodzenie. Dodatkowo rozmiary tzw. szarej strefy w Bułgarii powoduja tworzenie klimatu ułatwiającego proceder.

${ }^{38}$ Pełniący również funkcję wiceministra spraw wewnętrznych, odpowiedzialnego za walkę z korupcją i przestępczością zorganizowaną.

${ }^{39}$ Г. Петрунов, Прането на пари и мониторинговите доклади на Европейската комисия, Политики, Бр. 06/08, http://politiki.bg/?cy=111\&lan$\mathrm{g}=1 \& \mathrm{a} 0 \mathrm{i}=223141 \& \mathrm{a} 0 \mathrm{~m}=$ readInternal\&a0p_id=358 (dostęp 1 VII 2014).

${ }^{40}$ Годишен доклад за дейността на САД „Финансово разузнаване” - ДАНС за 2011 г., http://www.dans.bg/images/stories/fia-package/fiuannualreport2011-30052012.pdf (dostęp 15 V 2014). 
Należy też pamiętać, że, aby skutecznie walczyć z praniem pieniędzy, konieczne jest podjęcie działań w celu ograniczenia działalności przestępczej, dzięki której zarabiane są ogromne ilości brudnych pieniędzy. Dlatego walka z ich praniem nie powinna obejmować jedynie poprawę przepisów i optymalizację działań instytucji, związanych stricte z tym rodzajem przestępstw, lecz także kompleksowe działania w dziedzinie walki z przestępczością zorganizowana.

Analiza rozwiązań instytucjonalnych w zakresie przeciwdziałania praniu brudnych pieniędzy, przyjętych w Bułgarii, wskazuje na istotne ich podobieństwa z tymi w Polsce. Centralnym punktem obu systemów jest jednostka analityki finansowej, której główne zadanie polega na uzyskiwaniu, gromadzeniu, analizowaniu i przetwarzaniu informacji o dokonywanych transakcjach. Zapewnia to wiedzę o przepływach środków, jak również o poczynaniach konkretnych osób. Jednostki analityki finansowej w obu krajach pełnią rolę baz danych dla organów stanowiących elementy systemu zwalczania procederu prania brudnych pieniędzy. Należy zwrócić uwagę, że bułgarska Dyrekcja Wywiadu Finansowego do 2008 r. funkcjonowała (podobnie jak polski Generalny Inspektor Informacji Finansowej) przy Ministerstwie Finansów. Decyzja o rozpoczęciu walki z bułgarską przestępczością zorganizowaną na najwyższym szczeblu instytucjonalnym poskutkowała utworzeniem Państwowej Agencji „Bezpieczeństwa Narodowego” i umieszczeniem w jej strukturach organów odpowiedzialnych za walkę z praniem brudnych pieniędzy. Reforma nie spowodowała jednak nadania dodatkowych uprawnień jednostce analityki finansowej. Dlatego też kompetencje i zadania Dyrekcji Wywiadu Finansowego sa niezwykle zbliżone do tych, jakie posiada polska jednostka analityki finansowej. Pomimo licznych inicjatyw ustawodawczych oraz rosnącej liczby 
dochodzeń, dotyczących prania pieniędzy, liczba osób w Bułgarii skazanych za to jest nadal zbyt niska w stosunku do ujawnionych sum nielegalnych pieniędzy ${ }^{41}$, a organy ścigania sa zbyt mało aktywne $\mathrm{w}$ doprowadzeniu do ukarania sprawców.

${ }^{41}$ Инфбормация За Дейността На Прокуратурата На Република България По Основни Показатели За Периода 2007-2010 Година, http://www.prb.bg/uploads/documents/docs_2077.doc (dostęp 10 V 2014). 